\title{
Lack of clinical notes angered UAE judge in Karabus case
}

In an ironic twist, the absence of clinical notes sufficient to properly rule on manslaughter and forgery charges brought in the United Arab Emirates (UAE) against 77-year-old veteran Cape Town oncologist Professor Cyril Karabus may have led to his acquittal.

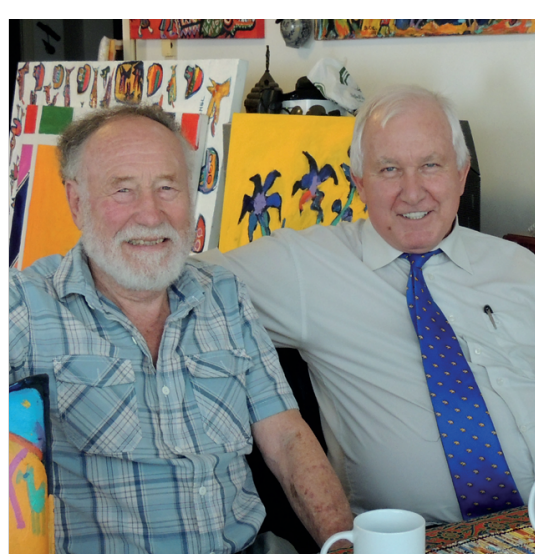

Professor Cyril Karabus, left, and his UAE artist/ gastro-enterologist host, Elwin Buchel.

Photo: Sjaan Buchel.

On 6 December the prosecution failed for the second time to produce clinical notes made during the critical two weeks Karabus treated a 3-year-old leukaemia patient at the Sheikh Khalifa Medical Centre (SKMC) in Abu Dhabi in 2002. The veteran specialist, for the first time in the nearly four months since his shock airport arrest, took the stand, telling the judge that the prosecution's failure to produce the notes amounted to 'an insult to the ruling Sheikh (Khalifa bin Zayed bin Sultan Al Nahyan) and the court'. The judge reportedly agreed with him and expressed deep dissatisfaction at the ongoing impasse which prevented a court-ordered medical committee from properly reviewing the case. Karabus' legal team saw the medical file for the first time at the 20 November hearing. (The child failed to respond to chemotherapy and succumbed with fever to intracranial bleeding and a middle cerebral arterial obstruction on 19 October 2002. )

Conspicuously absent were supportive notes (clinical records, laboratory blood count results, blood bank forms, nursing notes and infusion charts) to support Karabus' contention that he gave the child red cell and platelet transfusions. He is charged with manslaughter in that he allegedly failed to give platelets which led to her death, plus an additional count of forgery which claims he fraudulently wrote out instructions for the platelet administration after she died.

His dramatic detention came on 18 August after Karabus, his wife, Jennifer, daughter Sarah and Sarah's two children overnighted in Dubai en route from Canada to Cape Town, having attended his son's wedding. Sarah told Izindaba that she just missed witnessing the arrest which came at passport control after they returned to the airport to board the home-bound flight the following morning. Her mother was given five minutes to say goodbye and told she must board her home-bound flight. 'When we saw her she was completely traumatised,' she added.

Defence relying on one vital document - others 'missing'

Sarah, a paediatrician at the Chris Barnard Hospital in Cape Town, told Izindaba that while family spirits (Karabus senior has five children and his wife flew back to Abu Dhabi to support him) had flagged, they had pinned their hopes on one vital document their lawyers did have. This was a clinical record of the Yemeni patient's last admission, dictated by Karabus on 29 October 2002, and a document showing that her blood platelets increased from 1000 to 19000 the day before her cerebral episode - something that only a platelet infusion could have induced. His lawyer, Michael Bagraim, said they had hoped the medical panel would come to the same realisation, in what he described as 'an ongoing horror story'. He cautioned that under Sharia law, Karabus needed corroborating evidence (the missing hospital notes) to prove his innocence, but the judge's anger at the prosecution's failure to produce them at two consecutive hearings had probably worked in their favour.

Bagraim revealed that the local Abu Dhabi legal team appearing for Karabus had insisted on a R1 million (equivalent) retainer deposit - which international and local collegial generosity had covered. Karabus had no legal indemnity cover, he said, adding that because of pride in his reputation, his client flatly turned down his urgings and those of several intermediaries to plead guilty, pay a negotiated sum of 'blood money' and secure a ticket home.

'Basically he told me to put it in my pipe and smoke it. He wouldn't say "I did wrong" and then go home when it wasn't true. His good name is worth more to him than his freedom. $\mathrm{He}$ insisted on facing his responsibilities that's the type of guy I'm dealing with.'

Karabus' dilemma evoked world-wide support and sympathy from colleagues and a range of medical and human rights organisations, all of whom vouched for his integrity and impeccable record at the forefront of South African public sector paediatric oncology and haematology, both as a clinician and a teacher. Sarah Karabus' greatest fear was that the mysterious disappearance of the vital supportive notes depicting the week her father was treating the Yemeni girl may have been destroyed - or 'doctored'. She said no postmortem examination had been done. Bagraim quoted the legal advisor to the hospital as saying that the 2003 'in-absentia' court had ordered the hospital records in the matter destroyed. 'If that's the case then they don't exist and we have to wonder what will happen, Baigram told Izindaba in late November. 


\section{UAE justice record 'shaky'}

Sarah Karabus cited the case of Dr Eugene Adelsmayer, an Austrian convicted of murder in absentia last October by a Dubai court. He was accused of having switched off the life support system of a quadriplegic patient in February 2009 and issuing a 'do not resuscitate' order to staff. Adelsmayer reportedly took a copy of the medical files with him when he left Dubai in September 2011 and claims the files produced by the prosecution at the trial were 'notably different'. He was sentenced to life imprisonment (in absentia) and is now in a Catch 22 situation where he cannot appeal the verdict from afar, or risk returning to do so. Bagraim said this (kind of thing) was 'precisely what made us so nervous. If the prosecution came up with a strong counter-version, the outcome was potentially horrific'.

Karabus was initially tried in absentia in 2003 and found guilty of murder (which is why he was arrested), but this was later set aside on appeal (after his arrest) and downgraded to manslaughter. His family and lawyer say that at no point was Karabus ever contacted by the SKMC, where he did the five-week locum stint in 2002, treating the Yemeni child for acute myeloid leukaemia.

\section{Daughter fears for Karabus' life}

Karabus has a pacemaker and a stent and was held in an Abu Dhabi jail clinic for 57 days with 16 other prisoners. For each of his five bail appearances (the last, on 14 October, was successful, bail being set at R240 000) some 50 - 100 prisoners were lined up in the hot sun in the prison courtyard, shackled hand and foot, while their names were called, the now grey-bearded oncologist told Izindaba. Bagraim singled out the Anglican Church of Abu Dhabis' Reverend Canon Andy Thompson, contacted by Archbishop Desmond Tutu, as having been pivotal in helping make Karabus' life 'more comfortable'. Izindaba made contact with Karabus at the hotel he was staying at with his wife shortly after his 20 November hearing. He spent most of his time with Pretoria-trained gastro-enterologist and acclaimed artist Elwin Buchel, a UAE veteran of 11 years. Karabus said he was forced to grow his beard after prison officials took away his razor, but 'left it on in an attempt to appear older' at the numerous bail hearings. 'It didn't work very well', he joked.

Speaking shortly before his 6 December hearing, he said: 'There are many South Africans here and most have stories of bad experiences, but put up with things. One thing I've learned is that nothing happens quickly, and though I hope things will be resolved next week, one never knows. Luckily I have a record of my patient's stay in hospital, which I dictated on 29 October 2002 (she died on 19 October 2002), and which for some inexplicable reason Lourens de Jager (for whom I did the locum between 19 September and about 1 November) kept all these years and sent me. This gives all the details, which would exonerate me of negligence, but one needs the hospital records to confirm it. Just hope they, with the clinical notes, blood counts and blood bank records, will be available for the next hearing, he said.

Sarah described her father as 'very pragmatic, not easily shaken, very thoughtful and not prone to rash things at all. He's very precise. But he got pretty despondent, as you can imagine.' Because of his medical condition, she feared for his life should he be convicted. (He faced a minimum three-year jail term imposed by a criminal justice system in which the burden of proof lies with the defendant.) Karabus was upbeat about his health, adding that the South African consulate had sourced and provided much of the essential medication he needed while in jail.

Sarah Karabus said both Foreign Affairs and the UAE ambassador had been in contact with her family on a 'regular basis' to 'render consular assistance', but had stressed that they would not 'interfere with the process at all. This fell way short of South Africa's Treatment Action Campaign
(TAC) demands. They said the SA embassy had done 'almost nothing' to assist, and lambasted SA's Minister of International Relations and Co-operation. They called for a boycott of the Emirates airline, whose staff drew Karabus' attention to 'some form of security alert attached to his name' (but would not elaborate) when he first boarded in Canada.

\section{Emirates 'failed to warn' Karabus}

A TAC spokesperson expressed 'astonishment' that the Emirates airline failed to warn Karabus that he was wanted in the UAE and called on all travellers 'who share our abhorrence for the UAE's justice system to stop flying Emirates and to not visit the UAE'.

Letters and e-mails expressing outrage and backing Karabus' integrity and reputation have poured in to the media and family members. They include an emergency resolution by the World Medical Association condemning his arrest (unanimously supported by all 102 constituen members), Amnesty International, Human Rights Watch, the British and American medical associations, the SA Haemophilia Federation, the SA Medical Association (SAMA), the Western Province Blood Transfusion Service and the School of Child and Adolescent Health at UCT. Professor Heather Zar, Head of the Department of Paediatrics and Child Health at the Red Cross Children's Hospital, said Karabus had a 'sterling reputation', having pioneered treatment access for South African and African children and trained many of the leading healthcare professionals in the field today. 'The notion that he could have been negligent is outrageous', she fumed.

Dr Philip Lanzkowsky, of New York, who worked in clinical haematology at Red Cross Children's Hospital in 1965, said it was 'an unfortunate fact that children with leukaemia often die from the disease, complications of the disease or complications of therapy' Lanzkowsky was an expert witness at several landmark malpractice suits involving childhood malignancies, including leukaemia. Sarah Karabus warned colleagues using locum agencies employing doctors in foreign countries that 'they may not assist when it comes to the crunch', citing her father's case.

Interhealth Canada (IC) has denied any responsibility for legally assisting Professor Karabus, saying it ceased operating the hospital in 2003. A spokesman said: 'The charges which it seems were brought against Dr Karabus were brought under the criminal law and the costs of his defence against criminal charges would not have been covered by our or any other medical malpractice policy of which I am aware.' He said that at no time was IC informed of any complaint in relation to Dr Karabus' performance of his clinical duties (which Karabus refutes), that no complaint was made against either IC or [the hospital] and that no claim was made under IC's medical malpractice policy. The company said it had struggled to establish what happened at the time because it no longer managed the hospital and had transferred all records to UAE authorities. However, Karabus claims to have a letter from the director of the SKMC up to December 2003, Dr John Morse, saying that 'the patient's chart was requisitioned in October 2002 and I was in attendance as the chart was closely reviewed by the police. Morse was apparently unaware of the 23 March 2004 trial verdict. Another former SKMC doctor, Howard Parsons, a former head of paediatrics there, also reportedly knew police were probing the child's death. Izindaba has learnt that the health authority in Abu Dhabi paid an undisclosed sum (or 'blood money') to the child's father in a civil settlement but was unable to establish whether IC had reimbursed them.

For further information contact: help.prof.karabus@gmail.com

\section{Chris Bateman}

chrisb@hmpg.co.za

S Afr Med J 2013;103(1):14-15. DOI:10.7196/SAMJ.6603 